\title{
Cell Respiration of Rat Cardiomyocytes and Soleus Muscle Fibers under Ultra-Short-Term Antiorthostatic Suspension
}

\author{
Irina V. Ogneva, PhD, ScD*; Nikolay S. Biryukov, MSc; Oxana M. Veselova, $\mathrm{PhD}$; \\ Irina M. Larina, MD, ScD \\ SSC RF Institute of Biomedical Problems of RAS \\ Moscow, Russian Federation
}

\begin{abstract}
The aim of the study was to analyses rat soleus fibers and left ventricle (LV) cardiomyocyte cell respiration after $6,12,18$, 24 and 72 hours of antiorthostatic suspension by the tail. We measured $\mathrm{V}_{0}$ - basal oxygen consumption rate, $\mathrm{V}_{\text {Glu+Mal }}-$ respiration velocity over a catalyst of malate and glutamate $\left(5 \mathrm{mM}\right.$ glutamate $+2 \mathrm{mM}$ malate) and $\mathrm{V}_{\max }$ - maximal respiratory rate (in the presence of $1 \mathrm{mM}$ ADP) using the Saks polarography technique. We also determined the cytochrome $c$ content and expression of its gene $(\mathrm{Cycs})$ and the GAPDH gene using Western blotting and real-time PCR.

Cell respiration parameters in cardiomyocytes increased after 18 hours of suspension: $\mathrm{V}_{0}$ increased by $35 \%, \mathrm{~V}_{\text {Glu+Mal }}$ by $90 \%$ and $\mathrm{V}_{\max }$ by $85 \%$ in comparison with the control group $(\mathrm{p}<0.05)$. Cytochrome $c$ content in a mix of the membrane and mitochondrial fractions grew by $34.6 \%(\mathrm{p}<0.05)$ compared to control after 18 hours. However, Cycs and Gapdh expression rates remained stable. Protein content increase in this case may result from increased translation efficiency and/or a reduction in the level of proteolysis.

Intensity of soleus fiber cell respiration decreased after 72 hours of suspension, $\mathrm{V}_{0}$ decreased by $76 \%, \mathrm{~V}_{\text {Glu }+ \text { Mal }}$ by $59 \%$ and $\mathrm{V}_{\max }$ by $53 \%$ compared to controls $(\mathrm{p}<0.05)$. Cytochrome $c$ content fell after 24 hours of suspension by $15.7 \%(\mathrm{p}<0.05)$ and by $57.9 \%(\mathrm{p}<0.05)$ after 72 hours relative to controls. At the same time, Cycs mRNA content decreased after 6 hours of unloading by $23 \%(\mathrm{p}<0.05)$ and continued to decrease to $59 \%(\mathrm{p}<0.05)$ of the control level after 72 hours.
\end{abstract}

Keywords: cytochrome c; microgravity; skeletal muscle; myocardium.

\section{Introduction}

Reduction of muscle-system functional abilities follows from long-term weightlessness or hypokinesic conditions. Firstly, these conditions affect postural muscles, particularly the M. soleus muscle [1,2]. Additionally, weightlessness results in cardiovascular system changes, i.e., a fluid shift in a cranial direction [3,4] and a change in heart-stroke volume [5-7].

Cell inner-energy exchange parameters also contribute to negative consequences in muscles due to gravitational unloading. It appears in content change in substrates (glycogen and triglycerides) [8-11] and in cell respiration parameters $[12,13]$. Respiratory rate depends on the Krebs cycle fermentation activity, electron transition chain conditions and

*Corresponding author: Prof. Irina V. Ogneva, PhD, ScD; SSC RF Institute of Biomedical Problems of RAS. Moscow, Russian Federation.E-mail: iogneva@yandex.ru mitochondrial membrane ADP permeability.

Gravitational unloading does not result in a significant change in malate dehydrogenase in the soleus muscle [14], succinate dehydrogenase [15], or citrate synthase [16]. However, Ohira et al. [17] showed a reduction in citrate synthase activity after 10 days of rat hind-limb suspension.

One can talk about the influence of the Krebs cycle fermentation activity on the cell respiration parameters only if the respiration chain remains in the same state. Ohira et al. [17] and Oishi et al. [18] showed that gravitational unloading of 10 and 14 days' duration resulted in reduction of cytochrome oxidase activity in rat soleus fibers. This fact may indicate mitochondrial respiratory chain malfunction, since cytochrome oxidase catalysis the final stage of electron transition into oxygen during the oxidative phosphorylation process. At the same time Bigard et al. [16] showed that three-weeks' unloading does not lead to significant changes in oxygen consumption by skinned soleus fibers.

Such parameters in the cardiovascular system vary 
greatly. Most researchers noted fluid shift and hypovolaemia in rats under antiorthostatic suspension [19-21]. In addition, Shellock et al. [22] showed the magnitude of these effects to be dependent on the suspension angle. Short-term effects lead to a bulk-load increase on the heart by cardiopulmonary receptor activation [23]. Yin et al. [24] and Cui et al. [25] showed that the rats' heart mass and arterial pressure remained at the control level, but pressure in the left ventricle decreased. Baroceptor reflex sensitivity also does not differ after a 14-day suspension [26]. These data show that the effects of the acute period have been compensated for at this moment.

However, there are data about contractibility loss in rats' hearts due to long-term suspension [27-29]. Dunlap et al. [30] showed the maximal contraction force to be reduced by $15 \%$ after a seven-day suspension. Calcium sensitivity changed in the same way. According to the authors, this may occur due to a change in the expression rate of contractile proteins as a result of a bulk-load increase in the heart.

A number of authors detected a loss of myocardial contractile ability and a decrease in oxygen consumption under long-term suspension [31,32]. However, Bigard et al. [16] did not find any change in rat cardiomyocyte cell respiration after a three-week suspension. Oxidative fermentation and mitochondrial creatine kinase activity increased in rats' right ventricle after two weeks of suspension [33].

Respiratory rate can also be affected by ADP concentration in mitochondria, depending on external membrane permeability. This permeability is regulated by cytoplasmic proteins, and seems to be connected to cytoskeletal proteins [34]. Desmin may play this role, according to experiments with null-desmin mice $[35,36]$.

It is known that mitochondria are connected to the cytoskeleton, which has been proved by a number of investigations [37-42]. However, the role of the cytoskeleton in regulating mitochondrial function remains unclear. Ultrastructural analysis of different types of cells showed the obvious connection between mitochondria and desmin intermediate filaments [43-45]. An anomalous accumulation of subsarcolemmal mitochondria clusters was detected in soleus fibers of null-desmin mice [36]. These authors also showed that both oxygen consumption rate and the ADP dissociation constant were significantly reduced in comparison with the control group [36].

On the other hand, desmin is anchored to the submembrane cytoskeleton and one can suppose that the change in the cortical cytoskeleton structure will lead to a change in respiratory rate. We showed previously that the cortical cytoskeleton change occurs at early stages of antiorthostatic suspension ( 6,12 hours) in both soleus fibers and cardiomyocytes. Since cell respiration is one of the basic indexes of cell functional activity, the aim of this study was to analyses cell respiration parameters during ultra-short-term antiorthostatic suspension.

\section{Materials and Methods}

Experiments were performed with the tissue of the left ventricle and the soleus muscle of a Wistar rat $(n=42)$ weighing 225 to $255 \mathrm{~g}$. To simulate the microgravity conditions in rodents, antiorthostatic suspension was used according to the Ilyin-Novikov method modified by Morey-Holton et al. [46]. Control animals were housed under vivarium conditions and received standard food and water ad libitum. The duration of suspension was $6,12,18,24$ and 72 hours. The following groups were created: «Control», «6h», «12h», «18h», «24h» and « $72 \mathrm{~h} »$, with seven animals in each group.

All procedures with animals were approved by the biomedical ethics committee of the State Research Center of Russia at the Institute of Biomedical Problems of the Russian Academy of Sciences.

\section{Cell respiration by polarography}

The parts of the tissues of the left ventricle and soleus muscle were prepared according to the standard method described by Saks et al. [47], and cell respiration was estimated by polarography.

For exogenous substrates of the respiratory chain, we used a mix of $5 \mathrm{mM}$ glutamate and $2 \mathrm{mM}$ malate, and added $1 \mathrm{mM}$ ADP to determine the maximum respiration rate. Changes of oxygen concentration were measured using Clark's electrode and YSI Model 53 Oxygen Monitor (Yellow Spring Instrument Co., USA) at $22^{\circ} \mathrm{C}$. The solubility of oxygen in $1 \mathrm{ml}$ of the incubation environment at this temperature was assumed to be 460ng-at [48].

The following parameters of respiration were measured: $\mathrm{V}_{0}$ - basal oxygen consumption rate, $\mathrm{V}_{\mathrm{Glu}+\mathrm{Mal}}$ - respiration rate on substrates (5 mM glutamate $+2 \mathrm{mM}$ malate) and $\mathrm{V}_{\max }$ maximum respiration rate (in the presence of $1 \mathrm{mM}$ ADP). After the measurements, the fibers were extracted from the polarographic cell, dried at $95^{\circ} \mathrm{C}$ and weighed to calculate the rates per $\mathrm{mg}$ of dry weight (ng-at $\mathrm{O} \cdot \mathrm{min}^{-1} \mathrm{mg}^{-1}$ ). Respiratory ratio (RR) was calculated as the respiration rate in the presence of ADP to the respiration rate of exogenic substrates. We tested $\mathrm{n}=7$ samples from each group.

\section{Protein content by Western blotting}

In order to determine the protein content, a portion of the rat's left ventricle and soleus muscle was frozen at the temperature of liquid nitrogen. The method described in Vitorino et al. [49] was used to prepare tissue extracts and to obtain the mitochondrial membrane and cytoplasmic fraction of proteins. Denaturing polyacrylamide gel electrophoresis was performed using the Laemmli method and the Bio-Rad system (USA). Based on the measured concentration of the total fraction protein content, equal amounts of protein were added to each well. The transfer to the nitrocellulose membrane was performed using the method of Towbin et al. [50].

In order to determine the level of cytochrome $c$, specific monoclonal primary antibodies based on mice immunoglobulins were used (Santa Cruz Biotechnology, Inc.) at the manufacturer's recommended dilution (1:200). For secondary antibodies, we used biotinylated goat antibodies against mice IgG (Santa Cruz Biotechnology, Inc.) diluted 1:5000.

Afterwards, all membranes were treated with streptavidin conjugated with horseradish peroxidase (Sigma, 
Germany) diluted 1:5000. Protein bands were identified using 3,3'-diaminobenzidine (Merck, USA).

\section{mRNA by real-time PCR}

For estimating the expression level, total cellular RNA from frozen rat tissues of soleus muscles and heart left-ventricles was isolated using an RNeasy Micro Kit (Qiagen, Germany) according to the manufacture's protocol. Amplifications of transcripts were performed using $500 \mathrm{ng}$ of total RNA and one-step reverse transcription RT-PCR system (Qiagen, Germany) according to the manufacturer's protocol. The PCR primer sequences used in this study were designed using Primer3Plus software (Table 1).

The results obtained during the experiments were statistically processed with ANOVA, using a post-hoc t-test with a confidence level $\mathrm{p}<0.05$ to evaluate the certainty of difference between the groups. The mean (M) and standard error of the mean (SEM) were calculated.

Table 1.

RT-PCR primers and products

\begin{tabular}{|c|c|c|c|}
\hline Gene & Direction & Primer sequence (5'...3') & Product size, bp \\
\hline \multirow{2}{*}{ Cycs } & Forward & ccaaatctccacggtctgtt & \multirow{2}{*}{190} \\
\cline { 2 - 3 } & Reverse & tctgccctttctccttctt & \\
\hline \multirow{2}{*}{ Gapdh } & Forward & acccagaagactgtggatgg & \multirow{2}{*}{172} \\
\cline { 2 - 3 } & Reverse & acacattgggggtaggaaca & \\
\hline
\end{tabular}

\section{Results}

Dynamics of the cell respiration parameters of the rat leftventricle cardiomyocytes and soleus muscle fibers under short-term antiorthostatic suspension

All cell respiration parameters of the rat left-ventricle cardiomyocytes (Table 2, Fig. 1A) increased after 18 hours and remained high up to 72 hours of the antiorthostatic suspension: the basal respiration rate $\left(\mathrm{V}_{0}\right)$ increased by $35 \%(\mathrm{p}<0.05)$, the respiration rate on exogenous substrates $\left(\mathrm{V}_{\mathrm{Glu}+\mathrm{Mal}}\right)$ by $90 \%(\mathrm{p}<0.05)$, and the maximum respiration rate determined by adding ADP $\left(\mathrm{V}_{\max }\right)$ by $85 \%(\mathrm{p}<0.05)$ compared to the group «Control».

Parameters of the cell respiration of the rat SM fibers did not differ from the control group up to the 72 hours of the AS. After 72 hours all parameters decreased.

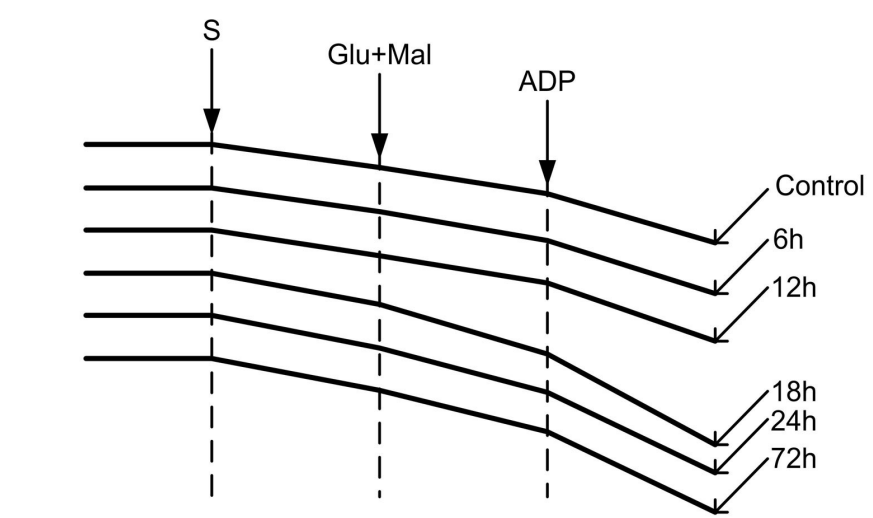

25 ng-at $\mathrm{O} / \mathrm{mg}$

A $1 \mathrm{~min}$

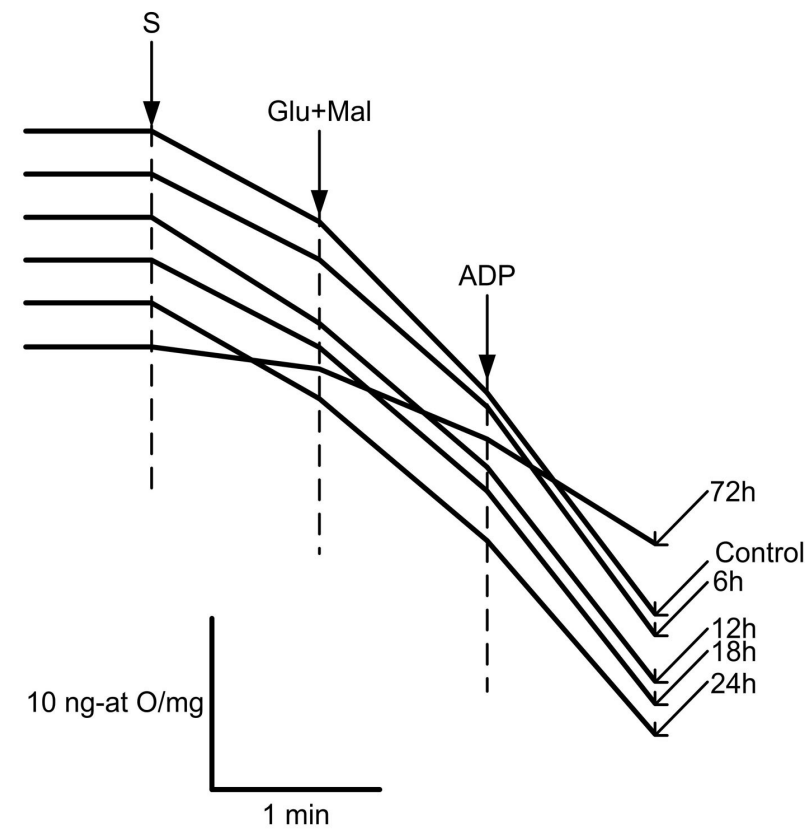

B

Figure 1. Averaged curves of the oxygen consumption by rat left-ventricle cardiomyocytes (A) and soleus muscle fibres (B) under under antiorthostatic suspension of different short durations. (A) - mentioned two groups of parallel curves: cardiomyocyte cell respiration increased after 18 hours of the antiorthostatic suspension and after it cell respiration parameters remained elevated up to 72 hours. (B) - soleus fiber cell respiration parameters decreased after 72 hours, that is significantly later than the cardiomyocytes, but were more pronounced.

Table 2.

Cell respiration parameters of the rat $L V$ cardiomyocytes under short-term antiorthostatic suspension

\begin{tabular}{|c|c|c|c|c|}
\hline Group Parameter & \begin{tabular}{|c|}
$\mathrm{V}_{0}$ \\
ng-at $\mathrm{O}^{\prime} \mathrm{min}^{-1} \mathrm{mg}^{-1}$
\end{tabular} & $\begin{array}{c}\mathrm{V}_{\text {Glu+Mal' }} \\
\text { ng-at O'min } \\
m^{-1} \mathrm{mg}^{-1}\end{array}$ & \begin{tabular}{|l}
$\mathrm{V}_{\max }$ \\
ng-at $\mathrm{O}^{-1} \mathrm{~min}^{-1} \mathrm{mg}^{-1}$
\end{tabular} & Respiration ratio \\
\hline Control $(n=7)$ & $13.5 \pm 1.6$ & $15.3 \pm 1.8$ & $28.7 \pm 2.5$ & $1.91 \pm 0.20$ \\
\hline $6 \mathrm{~h}(\mathrm{n}=7)$ & $13.8 \pm 1.4$ & $16.9 \pm 2.2$ & $31 \pm 3$ & $2.0 \pm 0.3$ \\
\hline $12 \mathrm{~h}(\mathrm{n}=7)$ & $15.0 \pm 1.1$ & $15.9 \pm 1.1$ & $34 \pm 4$ & $2.2 \pm 0.3$ \\
\hline $18 \mathrm{~h}(\mathrm{n}=7)$ & $18.2 \pm 1.9 *$ & $29 \pm 3 *$ & $53 \pm 3 *$ & $2.1 \pm 0.3$ \\
\hline $24 \mathrm{~h}(\mathrm{n}=7)$ & $19.1 \pm 1.2 *$ & $25.9 \pm 1.9 *$ & $47 \pm 4 *$ & $1.83 \pm 0.13$ \\
\hline $72 \mathrm{~h}(\mathrm{n}=7)$ & $18.6 \pm 1.3^{*}$ & $24.2 \pm 2.0^{*}$ & $47 \pm 5^{*}$ & $1.91 \pm 0.21$ \\
\hline
\end{tabular}

* $-p<0.05$ as compared to the Control 
Parameters of the cell respiration of the rat soleus muscle fibers (Table 3, Fig. 1B) did not differ from the control group up to the 72 hours of the antiorthostatic suspension. After 72 hours all parameters decreased: $\mathrm{V}_{0}$ decreased by $76 \%$ $(\mathrm{p}<0.05), \mathrm{V}_{\text {Glu }+ \text { Mal }}$ by $59 \%(\mathrm{p}<0.05)$ and $\mathrm{V}_{\max }$ by $53 \%(\mathrm{p}<0.05)$ compared to the group «Control».

The estimated value reflecting the efficiency of coupling of oxidation and phosphorylation, known as RR, during antiorthostatic suspension did not differ from that of the control group,nor did cardiomyocytes or soleus fibres.

Cytoskeletal protein content dynamic of left ventricle cardiomyocytes and soleus muscle fibers of rats after shortterm gravitational unloading

Cytochrome $c$ (CYCS) content (Fig. 2C) in the membrane fraction, which includes also the mitochondrial fraction, of rats' left ventricles increased after 18 hours of suspension by $34.6 \%(\mathrm{p}<0.05)$, after 24 hours by $79.2 \%(\mathrm{p}<0.05)$ and after 72 hours by $50.8 \%(\mathrm{p}<0.05)$ in comparison with the control level. In soleus fibers, CYCS content decreased after 24 hours of suspension by $15.7 \%(\mathrm{p}<0.05)$ and by $57.9 \%(\mathrm{p}<0.05)$ after 72 hours relative to control. However, we did not detect CYCS in the cytoplasmic fraction of either cardiomyocytes or soleus fibers.

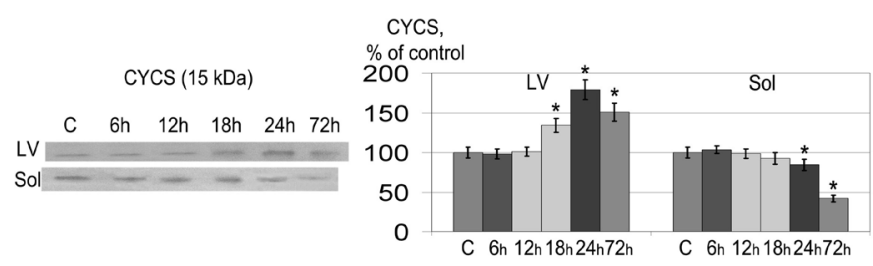

Figure 2. Relative CYCS content in the mitochondrial membrane protein fraction of left-ventricle cardiomyocytes $(L V)$ and soleus muscle fibres (Sol) of rats after short-term gravitational unloading and typical Western blot pictures; $* p<0.05$ as compared to the group «Control» indicated as $« C »$ in this figure.

Dynamic of expression level of genes encoding cytochrome $c$ and glyceraldehyde 3-phosphate dehydrogenase, in leftventricle cardiomyocytes and soleus muscle fibers of rats after short-term gravitational unloading

The expression level of cytochrome $c$ gene (Cycs) and glyceraldehyde 3-phosphate dehydrogenase gene (Gapdh) in rats' left-ventricle cardiomyocyctes did not change during the antiorthostatic suspension. In soleus fibers, Cycs mRNA (Fig. $3, \mathrm{~A})$ decreased by $23 \%(\mathrm{p}<0.05)$ in group «6h» and continued to fall, dropping by $41 \%(\mathrm{p}<0.05)$ at 72 hours compared to the control level.
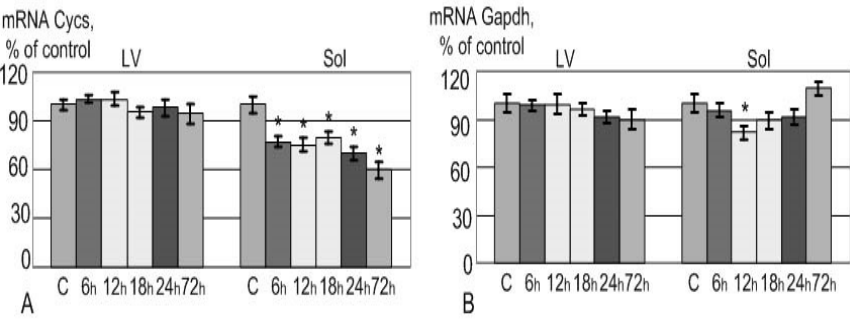

Figure 3. Expression level of genes encoding metabolic proteins, in leftventricle cardiomyocytes ( $L V$ ) and soleus muscle fibers (Sol) of rats after shortterm gravitational unloading; * $p<0.05$ as compared to the group "Control» indicated as «C» inthis figure. A-cytochrome c gene (Cycs), B-glyceraldehyde 3-phosphate dehydrogenase gene (Gapdh).

The expression level of Gapdh (Fig. 3, B) decreased by 19\% $(\mathrm{p}<0.05)$ in comparison with «control» after 12 hours of unloading, but after 18 hours was restored to the control level and remained unchanged during the following period.

\section{Discussion}

It was shown that stretching/compression of the muscle cell membrane may influence mitochondria functioning by the mean of cytoskeleton [51,52]. An anomalous accumulation of subsarcolemmal mitochondria clusters was detected in soleus fibers of null-desmin mice [36], and these authors also showed a decrease in the rate of oxygen consumption.

Saks et al. [53] also showed that oxygen consumption depends on the cytoskeletal state. Our previously obtained data showed that the velocity of basal cell respiration in a rat's cardiomyocytes significantly increased after one day of suspension, but after three days returned to the control level. However, other cell respiration parameters significantly increased after 24 hours and remained high during 14 days. Three days of recovery resulted in a significant reduction in all parameters compared to the control level [13]. Moreover, there was an increase of the relative content of desmin in cardiomyocytes [13]. Desmin is necessary to determine localization and regulate permeability.

Under gravitational unloading, the respiratory rate of soleus fiber cells decreased after three days, reached its minimum after seven days, and slightly grew to the $14^{\text {th }}$ day. This result correlates with desmin content dynamics [55,56]. Three days of recovery resulted in a significant reduction in cell respiratory rate, although it returned to the control level after seven days of readaptation [57].

Table 3.

Cell respiration parameters of the rat soleus muscle fibres under short-term antiorthostatic suspension

\begin{tabular}{|c|c|c|c|c|}
\hline Group & $\begin{array}{c}\mathrm{V}_{0}, \\
\text { ng-at O-min }{ }^{-1} \cdot \mathrm{mg}^{-1}\end{array}$ & $\begin{array}{c}\mathrm{V}_{\text {Glu+Mal }} \\
\text { ng-at O'min } \text { mg-1 }^{-1}\end{array}$ & $\begin{array}{c}\mathrm{V}_{\max }, \\
\text { ng-at } \mathrm{O} \mathrm{min}^{-1} \mathrm{mg}^{-1} \\
\end{array}$ & Respiration ratio \\
\hline Control $(\mathrm{n}=7)$ & $5.3 \pm 0.7$ & $9.9 \pm 1.2$ & $13.0 \pm 1.2$ & $1.43 \pm 0.21$ \\
\hline $6 \mathrm{~h}(\mathrm{n}=7)$ & $5.0 \pm 0.4$ & $8.6 \pm 0.5$ & $13.3 \pm 1.1$ & $1.6 \pm 0.3$ \\
\hline $12 \mathrm{~h}(\mathrm{n}=7)$ & $6.2 \pm 0.6$ & $8.4 \pm 0.8$ & $12.5 \pm 0.5$ & $1.55 \pm 0.13$ \\
\hline $18 \mathrm{~h}(\mathrm{n}=7)$ & $5.1 \pm 0.6$ & $8.4 \pm 0.6$ & $1.4 \pm 0.7$ & $1.57 \pm 0.13$ \\
\hline $24 \mathrm{~h}(\mathrm{n}=7)$ & $5.6 \pm 0.7$ & $8.3 \pm 0.5$ & $11.3 \pm 1.3$ & $1.49 \pm 0.18$ \\
\hline $72 \mathrm{~h}(\mathrm{n}=7)$ & $1.29 \pm 0.09 *$ & $4.1 \pm 0.4^{*}$ & $6.1 \pm 0.8^{*}$ & $1.63 \pm 0.28$ \\
\hline
\end{tabular}

* $-p<0.05$ as compared to the Control 
At the same time, desmin content in the soleus muscle was higher than the control level by $50 \%$ after one day of suspension and by $67 \%$ after three days [55]. Nevertheless, the respiratory rate decreased after two days of unloading by $37 \%$ in subsarcolemmal mitochondria obtained from the soleus muscle [56].

Since desmin mostly localizes in the Z-disk area and connects it to the submembrane cytoskeleton [59], one can assume that the condition of the cortical cytoskeleton influences the respiratory rate. For example, alpha-actinin- 4 - one of cytoskeletal proteins - may bind with the promoter region of the cytochrome $c$ gene, resulting in its expression level change [60].

We showed earlier that alpha-actinin-1 content was reduced after six hours of suspension (in cardiomyocytes) and alpha-actinin-4 (in soleus fibers) in the membrane fraction and increased in the cytoplasmic fraction. The expression level of beta- and gamma-actin, and alpha-actinin- 1 and 4 genes decreased after 6 and 12 hours, but alpha-actinin- 1 gene expression was restored after 72 hours. Beta-actin and alphaactinin-4 gene expression increased after 18 and 24 hours [61]. For this reason, we decided to analyses cell respiration parameters after ultra-short-term antiorthostatic suspension.

The respiratory rate increase in cardiomyocytes appeared after 18 hours of suspension, which might be connected with an increase in the efficiency of respiration chain terminal stages or with an increase in the number of respiration chain complexes. Since the respiration control level - i.e. the coupling of oxidation and phosphorylation remains stable through all suspension periods, the second way is more probable. We analyzed cytochrome $c$ content (one of the key components of the respiration chain) and showed that it increased after 18 hours of suspension. However, its gene expression rate remained unchanged throughout, as did gapdh expression. All these facts about protein content and expression of their genes may point to either an increase in translation efficiency or a reduction in proteolysis activity.

At the same time, a reduction in Cycs expression was observed in soleus fibers after six hours of suspension, and a decrease in protein content occurred after 24 hours by $15.7 \%(\mathrm{p}<0.05)$ and after 72 hours by $57.9 \%(\mathrm{p}<0.05)$. Cell respiration intensity also reduced after 72 hours.

Differently directed cell respiration change takes place in rat cardiomyocytes and soleus fibers. Protein content changes were also different: alpha-actinin-1 dissociates in the cytoplasm in cardiomyocytes; in soleus fibers it was alphaactinin-4 [61].

Taking into account data obtained by Goffart et al. [60], one can suppose that alpha-actinin-4 in soleus fibers may migrate into the nucleus, where it binds to the Cycs promoter region and inhibits its expression. As a result, the number of respiratory chain complexes is reduced and we observe cell respiration parameters to decrease.

Perhaps another mechanism takes place in cardiomyocytes. Alpha-actinin-1 dissociates from the cortical cytoskeleton, interacting with phospholipase-D and inhibiting its activity [62]. Phospholipase-D, liberated due to alphaactinin-1 dissociation, regulates the efficiency of translation and protein synthesis. Without a change in Cycs expression, it may lead to an increase of cytochrome $c$ content, and as a result to an increase in the number of respiratory chains.

\section{Grants}

The financial support of the Russian Fond of the Basic Research (RFBR grant 13-04-00755-a) is greatly acknowledged.

\section{Competing interests}

The authors declare that they have no competing interests.

\section{REFERENCES}

1. Caiozzo VJ, Haddad F, Baker MJ, Herrick RE, Prietto $\mathrm{N}$, Baldwin KM. Microgravity-induced transformations of myosin isoforms and contractile properties of skeletal muscle. J Appl Physiol 81: 123-132, 1996.

2. Booth FW, Kelso JR. Effect of hind-limb immobilization on contractile and histochemical properties of skeletal muscle. Pflugers Arch 342: 231-238, 1973.

3. Thornton WE, Moore TP, Pool SL. Fluid shifts in weightlessness. Aviat Space Environ Med 58: A86-A90, 1987. 4. Watenpaugh DE, Hargens AR. The cardiovascular system in microgravity. In: Handbook of Physiology. Environmental Physiology, Am Physiol Soc, 4(vol. I, pt. 3, chapt. 29): 631674, 1996.

5. Nixon JV, Murray RG, Bryant C, Johnson RL Jr., Mitchell JR, Holland OB, et al. Early cardiovascular adaptation to simulated zero gravity. J Appl Physiol 46: 541-548, 1979.

6. Bungo MW, Goldwater DJ, Popp RL, Sandler H. Echocardiographic evaluation of space shuttle crewmembers. J Appl Physiol 62: 278-283, 1987.

7. Charles JB, Lathers CM. Cardiovascular adaptation to spaceflight. J Clin Pharmacol 31: 1010-1023, 1991.

8. Grichko VP, Heywood-Cooksey A, Kidd KR, Fitts RH. Substrate profile in rat soleus muscle fibers after hindlimb unloading and fatigue. J Appl Physiol 88: 473-478, 2000.

9. Baldwin KM, Herrick RE, McCue SA. Substrate oxidation capacity in rodent skeletal muscle: effects of exposure to zero gravity. J Appl Physiol 75: 2466-2470, 1993.

10. Riley DA, Ellis S, Slocum GR, Satyanarayana T, Bain JL, Sedlak FR. Hypogravity-induced atrophy of rat soleus and extensor digitorum longus muscles. Muscle Nerve 10: 560 568, 1987.

11. Widrick JJ, Knuth ST, Norenberg KM, Romatowski JG, Bain JL, Riley DA, et al. Effect of a 17 day spaceflight on contractile properties of human soleus muscle fibres. J Physiol 516: 915-930, 1999.

12. Yajid F, Mercier JG, Mercier BM, Dubouchaud H, Prefaut C. Effects of $4 \mathrm{wk}$ of hindlimb suspension on skeletal muscle mitochondrial respiration in rats. J Appl Physiol 84: 479-485, 1998.

13. Ogneva IV, Mirzoev TM, Biryukov NS, Veselova OM, Larina IM. Structure and functional characteristics of rat's left ventricle cardiomyocytes under antiorthostatic suspension of various duration and subsequent reloading. J Biomed Biotechnol 2012 (Article ID 659869): 11 pages, 2012.

14. Chi MM, Choksi R, Nemeth P, Krasnov I, Ilyina-Kakueva E, Manchester JK, etal.. Effects of microgravity and tail suspension on enzymes of individual soleus and tibialis anterior fibers. J Appl Physiol 73: 66-73, 1992. 
15. Ohira Y, Jiang B, Roy RR, Oganov V, Ilyina-Kakueva E, Marini JF, et al. Rat soleus muscle fiber responses to 14 days of spaceflight and hindlimb suspension. J Appl Physiol 73: 51-57, 1992.

16. Bigard A-X, Boehm E, Veksler V, Mateo P, Anflous K, Ventura-Clapier R. Muscle unloading induces slow to fast transitions in myofibrillar but not mitochondrial properties. Relevance to skeletal muscle abnormalities in heart failure. J Mol Cell Cardiol 30: 2391-2401, 1998.

17. Ohira Y, Yasui W, Kariya F, Wakatsuki T, Nakamura K, Asakura T, et al. Metabolic adaptation of skeletal muscles to gravitational unloading. Acta Astronaut 33: 113-117, 1994.

18. Oishi Y, Ogata T, Yamamoto KI, Terada M, Ohira T, Ohira Y, et al.. Cellular adaptations in soleus muscle during recovery after hindlimb unloading. Acta Physiol 192(3): 381395, 2008.

19. Hargens AR, Steakai J, Johansson C, Tipton CM. Tissue fluid shift, forelimb loading, and tail tension in tailsuspended rats. Physiologist 27: S37-S38, 1984.

20. Musacchia XJ, Deavers DR, Meininger GA. Fluid/ electrolyte balance and cardiovascular responses: head-down tilted rats. Physiologist 33: S46-S47, 1990.

21. McDonald KS, Delp MD, Fitts RH. Effect of hindlimb unweighting on tissue blood flow in the rat. J Appl Physiol 72: 2210-2218, 1992.

22. Shellock FG, Swan HJ, and Rubin SA. Early central venous pressure changes in the rat during two different levels of headdown suspension. Aviat Space Environ Med 56: 791$795,1985$.

23. Halet G, Viard P, Morel J-L, Mironneau J, Mironneau Ch. Effects of hindlimb suspension on cytosolic $\mathrm{Ca} 21$ and $[3 \mathrm{H}]$ ryanodine binding in cardiac myocytes. Am J Physiol (Heart Circ Physiol 45) 276: H1131-H1136, 1999.

24. Yin W, Liu J-C, Fan R, Sun X-Q, Ma J, Feng N, et al. Modulation of beta-adrenoceptor signaling in the hearts of 4-wk simulated weightlessness rats. J Appl Physiol 105: 569 $-574,2008$.

25. Cui Y, Zhang S-M, Zhang Q-Y, Fan R, Li J, Guo H-T, et al. Modulation of intracellular calcium transient in response to beta-adrenoceptor stimulation in the hearts of 4-wk-old rats during simulated weightlessness. J Appl Physiol 108: 838844, 2010.

26. Fagette S, Ming L, Claude Gh, Gauquelin G. Cardiovascular variability and baroreceptor reflex sensitivity over a 14-day tail suspension in rats. J Appl Physiol 78(2): 717-724, 1995.

27. Chen J, Zhang LF, Ma J. Ultrastructural changes of myocardium in long-term tail-suspended rats. J Chinese Aerospace Med 6: 133-137, 1995.

28. Zhang LF, Yu ZB, Ma J. Functional alterations in cardiac muscle after medium or long term simulated weightlessness and related cellular mechanisms. J Gravit Physiol 2: 5-8, 1995.

29. Yu Zh-B, Bao J-X, Ma J, Zhang L-F, Jin J-P. Changes in myocardial contractility and contractile proteins after four weeks of simulate weightlessness in rats. J Gravit Physiol 7(2): P147-P148, 2000.

30. Dunlap AW, Donald BT, Vandana M, Hofmann PA. Decreased $\mathrm{Ca} 2+$ sensitivity of isometric tension in skinned cardiac myocytes from tail-suspended rats. J Appl Physiol 80(5): 1612-1617, 1996.

31. Desplanches D, Mayet MH, Sempore B, Frutoso J, Flandrois R. Effect of spontaneous recovery or retraining after hindlimb suspension on aerobic capacity. J Appl Physiol 63: 1739-1743, 1987.

32. Overton JM, Woodman CR, Tipton CM. Effect of hindlimb suspension on $\mathrm{V}^{\cdot} \mathrm{O} 2$ max and regional blood flow responses to exercise. J Appl Physiol 66: 653-659, 1989.

33. Kunishima T. Ultrastructural and biochemical enzymatic properties of right ventricular muscles during hindlimb suspension in rats. Nihon Seirigaku Zasshi 55(4): 153-164, 1993.

34. Saks VA, Kuznetsov AV, Khuchua ZA, Vasilyeva EV, Belikova JO, Kesvatera T, et al. Control of cellular respiration in vivo by mitochondrial outer membrane and by creatine kinase. A new speculative hypothesis: possible involvement of mitochondrial-cytoskeleton interactions. J Mol Cell Cardiol 27: 625-645, 1995.

35. Kay L, Li Z, Mericskay M, Olivares J, Tranqui L, Fontaine $\mathrm{E}$, et al. Study of regulation of mitochondrial respiration in vivo. An analysis of influence of ADP diffusion and possible role of cytoskeleton. Biochim Biophys Acta 1322: 41-59, 1997.

36. Milner DJ, Mavroidis M, Weisleder N, Capetanaki Y. Desmin cytoskeleton linked to muscle mitochondrial distribution and respiratory function. J Cell Biol 150(6): 1283-1298, 2000.

37. Heggeness MH, Simon M, Singer SJ. Association of mitochondria with microtubules in cultured cells. Proc Natl Acad Sci USA 75: 3863-3866, 1978.

38. Martz D, Lasek RJ, Brady ST, Allen RD. Mitochondrial motility in axons: membranous organelles may interact with the force generating system through multiple surface binding sites. Cell Motil 4: 89-101, 1984.

39. Drubin DG, Jones HD, Wertman KF. Actin structure and function: roles in mitochondrial organization and morphogenesis in budding yeast and identification of the phalloidin-binding site. Mol Biol Cell 4: 1277-1294, 1993.

40. Bereiter-Hahn J, Voth M. Dynamics of mitochondria in living cells: shape changes, dislocations, fusion, and fission of mitochondria. Microsc Res Tech 27: 198-219, 1994.

41. Rappaport L, Oliviero P, Samuel JL. Cytoskeleton and mitochondrial morphology and function. Mol Cell Biochem 184: 101-105, 1998.

42. Yaffe MP. The machinery of mitochondrial inheritance and behavior. Science 283: 1493-1497, 1999.

43. Stromer MH, Bendayan M. Immunocytochemical identification of cytoskeletal linkages to smooth muscle cell nuclei and mitochondria. Cell Motil Cytoskeleton 17: 11-18, 1990.

44. Almahbobi G, Williams LG, Han XG, Hall PF. Binding of lipid droplets and mitochondria to intermediate filaments in rat Leydig cells. J Reprod Fertil 98: 209-217, 1993.

45. Georgatos SD, Maison C. Integration of intermediate filaments into cellular organelles. Int Rev Cytol 164: 91-138, 1996.

46. Morey-Holton E, Globus RK, Kaplansky A, Durnova $\mathrm{G}$. The hindlimb unloading rat model: literature overview, technique update and comparison with space flight data. Adv Space Biol Med 10: 7-40, 2005.

47. Saks VA, Veksler VI, Kuznetsov AV, Kay L, Sikk P, Tiivel $\mathrm{T}$, et al. Permeabilized cell and skinned fiber techniques in studies of mitochondrial function in vivo. Mol Cell Biochem 184(1-2): 81-100, 1998.

48. Seppet EK, Eimre M, Andrienko T, Kaambre T, Sikk P, Kuznetsov AV, et al. Studies of mitochondrial respiration in 
muscle cells in situ: use and misuse of experimental evidence in mathematical modelling. Mol Cell Biochem 256-257(1-2): 219-227, 2004.

49. Vitorino R, Ferreira R, Neuparth M, Guedes S, Williams J, Tomer KB, et al. Subcellular proteomics of mice gastrocnemius and soleus muscles. Anal Biochem 366(2): 156-169, 2007.

50. Towbin H, Staehlin T, Gordon J. Electrophoretic transfer of proteins from polyacrylamide gels to nitrocellulose sheets: procedure and some application. Proc Natl Acad Sci USA 76: 4350-4354, 1970.

51. Capetanaki, Y., Milner D. Desmin cytoskeleton in muscle integrity and function. Subcell Biochem 31: 463-495, 1998.

52. Capetanaki Y, Bloch RJ, Kouloumenta A, Mavroidis M, Psarras S. Muscle intermediate filaments and their links to membranes and membranous organells. Exp Cell Res 313: 2063-2076, 2007.

53. Saks V, Kuznetsov A, Andrienko T, Usson Y, Appaix F, Guerrero K, et al. Heterogeneity of ADP diffusion and regulation of respiration in cardiac cells. Biophys $\mathrm{J}$ 84(5): 3436-3456, 2003.

54. Mirzoev TM, Biryukov NS, Veselova OM, Larina IM, Shenkman BS, Ogneva IV. Parameters of fibers cell respiration and desmin content in rat soleus muscle at early stages of gravitational unloading. Biophysics 57(3): 509-514, 2012.

55. Ogneva IV. The transversal stiffness of fibers and the desmin content in the leg muscles of rats under gravitational unloading of various duration. J Appl Physiol 109: 1702-
1709,2010

56. Enns DL, Raastad T, Ugelstad I, Belcastro AN. Calpain/ calpastatin activities and substrate depletion patterns during hindlimb unweighting and reweighting in skeletal muscle. Eur J Appl Physiol 100: 445-455, 2007.

57. Mirzoev TM, Biryukov NS, Veselova OM, Larina IM, Shenkman BS, Ogneva IV. Content of desmin and energy substrates and cell respiration of the rat's $\mathrm{m}$. soleus fibers under 3 - and 7-day reloading after 14-day unloading. Aviakosm Ekolog Med 46(1): 41-45, 2012.

58. Krieger DA, Tate CA, McMillin-Wood J, Booth FW. Populations of rat skeletal muscle mitochondria after exercise and immobilization. J Appl Physiol 48: 23-28, 1980.

59. Paulin D, Li Z. Desmin: a major intermediate filament protein essential for the structural integrity and function of muscle. Exp Cell Res 301: 1-7, 2004.

60. Goffart S, Franko A, Clemen ChS, Wiesner RJ. a-Actinin 4 and BAT1 interaction with the Cytochrome c promoter upon skeletal muscle differentiation. Curr Genet 49: 125-135, 2006. 61. Ogneva IV, Biryukov NS, Leinsoo TA, Larina IM. Possible role of non-muscle alpha-actinins in the mechanosensitivity of muscle cells. PLoS ONE 9(4):e96395, 2014.

62. Park JB, Kim JH, Kim Y, Ha SH, Yoo JS, Du G, et al. Cardiac phospholipase D2 localizes to sarcolemmal membranes and is inhibited by alpha-actinin in an ADPribosylation factor-reversible manner. J Biol Chem 275(28): 21295-21301, 2000. 